\title{
Macrolepiotin, a new indole alkaloid from Macrolepiota neomastoidea
}

\author{
Ki Hyun Kim ${ }^{1}$, Ki Moon Park ${ }^{2}$, Sang Un $\mathrm{Choi}^{3}$ and Kang Ro Lee ${ }^{1}$
}

The Journal of Antibiotics (2009) 62, 335-338; doi:10.1038/ja.2009.30; published online 17 April 2009

Keywords: Agaricaceae; cytotoxicity; indole alkaloid; Macrolepiota neomastoidea; macrolepiotin

The fungi of the genus, Macrolepiota, are grouped under the family Agaricaceae (division Basidiomycota) and comprise $\sim 20$ species. Various biological activities of the genus, Macrolepiota, have been reported, including anti-microbial, antioxidant and enzyme (trypsin, monophenolase) activities. ${ }^{1-5}$ However, few species have been studied with regard to their secondary metabolites. Only several free amino acids, fatty acids and sterols have been reported from Macrolepiota excoriata, Macrolepiota procera and Macrolepiota thacodes. ${ }^{6}$ Therefore, as part of a systematic study of Korean mushrooms, ${ }^{7}$ we investigated the constituents of the fruiting bodies of the mushroom Macrolepiota neomastoidea, widely distributed throughout Korea and other East Asian countries. This is a poisonous mushroom known to cause severe gastrointestinal symptoms, including intestinal irritation, vomiting and profuse diarrhea. ${ }^{8}$ Thus far, little work has been done on the chemical constituents of $M$. neomastoidea, except for the isolation of two compounds, lepiotins A and B. ${ }^{9}$ Recently, we reported the isolation of lepiotin $\mathrm{C}$ and $(R)$-5-hydroxypyrrolidin-2-one, as well as lepiotins $\mathrm{A}$ and B. ${ }^{10}$ As part of a continuing study, we have further isolated a new indole alkaloid named macrolepiotin (1), together with four known ergosterols, $(22 E, 24 R)-5 \alpha, 8 \alpha$-epidioxyergosta-6,9,22-triene-3 $\beta$-ol (2), ${ }^{11} \quad(22 E, 24 R)-5 \alpha, 8 \alpha$-epidioxyergosta-6,22-dien-3 $\beta$-ol $(3),{ }^{12}(24 S)$-ergost-7-en- $3 \beta$-ol $(4)^{13}$ and $(22 E, 24 R)-5 \alpha, 6 \alpha$-epoxyer-

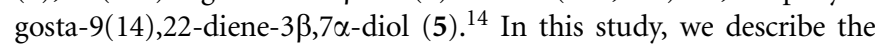
isolation and structural elucidation of $\mathbf{1}$ and the cytotoxic activities of compounds $\mathbf{1}-\mathbf{5}$.

\section{MATERIALS AND METHODS}

\section{General}

Optical rotations were measured on a Jasco P-1020 polarimeter (Jasco, Easton, MD, USA) in MeOH. IR spectra were recorded on a Bruker IFS-66/S FT-IR spectrometer (Bruker, Karlsruhe, Germany). UV spectra were recorded using a Schimadzu UV-1601 UV-visible spectrophotometer (Schimadzu, Kyoto, Japan). FAB and HR-FAB mass spectra were obtained on a JEOL JMS700 mass spectrometer (JEOL, Peabody, MA, USA). NMR spectra were recorded on a Varian UNITY INOVA 500 NMR spectrometer (Varian, Palo Alto, CA, USA) operating at $500\left({ }^{1} \mathrm{H}\right)$ and $125 \mathrm{MHz}\left({ }^{13} \mathrm{C}\right)$, respectively. Preparative HPLC was carried out using a Gilson 306 pump (Gilson, Middleton, WI, USA) with Shodex refractive index detector (Shodex, New York, NY, USA). Low-pressure liquid chromatography was carried out over a Merck Lichroprep Lobar-A Si 60 (Merck, Darmstadt, Germany) $(240 \times 10 \mathrm{~mm})$ or a Lichroprep Lobar-A RP-18 (Merck) $(240 \times 10 \mathrm{~mm})$ column using a FMI QSY-0 pump (Teledyne Isco, Lincoln, NE, USA). Silica gel 60 (Merck, 70-230 and 230-400 mesh) and RP$\mathrm{C}_{18}$ silica gel (Merck, 230-400 mesh) were used for column chromatography. Spots were detected on a TLC under UV light or by heating after spraying with $10 \% \mathrm{H}_{2} \mathrm{SO}_{4}$ in $\mathrm{C}_{2} \mathrm{H}_{5} \mathrm{OH}(\mathrm{v} / \mathrm{v})$.

\section{Mushroom material}

The fresh fruiting bodies of M. neomastoidea were collected in November 2005 at Mt Jiri, Namwon of Jeonbuk Province, Korea. A voucher specimen (SKKU2005-11) of the mushroom was deposited at the College of Pharmacy in Sungkyunkwan University, Korea.

\section{Extraction and isolation}

The air-dried and powdered fruiting bodies of M. neomastoidea (132 g) were extracted with $80 \% \mathrm{MeOH}$ at room temperature to afford a methanolic extract (21.4 g). This extract was suspended in $\mathrm{H}_{2} \mathrm{O}$ and partitioned with $n$-hexane, $\mathrm{CHCl}_{3}$ and $n$-BuOH successively, and the solvent was removed thereafter to yield $n$-hexane $(3.3 \mathrm{~g}), \mathrm{CHCl}_{3}(283 \mathrm{mg})$ and $n-\mathrm{BuOH}$ fractions $(10.4 \mathrm{~g})$. The $n$-hexane soluble fraction $(3.3 \mathrm{~g})$ was subjected to silica gel column chromatography with $n$-hexane-EtOAc (1:1) as the eluent to give seven fractions $(\mathrm{H} 1-\mathrm{H} 7)$. Fraction $\mathrm{H} 4(75 \mathrm{mg})$ was further purified by $\mathrm{RP}-\mathrm{C}_{18}$ preparative HPLC (Econosil RP-18 $10 \mu$ column, $250 \times 22 \mathrm{~mm} ; 100 \%$ $\mathrm{MeOH})$ to give pure compounds $2(6 \mathrm{mg})$ and $3(35 \mathrm{mg})$. The $\mathrm{CHCl}_{3}$ soluble fraction $\left(283 \mathrm{mg}\right.$ ) was subjected to a silica Lobar A-column with $\mathrm{CHCl}_{3}-\mathrm{MeOH}$ (10:1) as the eluent to give seven fractions $(\mathrm{C} 1-\mathrm{C} 7)$. Fraction $\mathrm{C} 4(55 \mathrm{mg})$ was further purified using a silica gel Waters Sep-Pak Vac $6 \mathrm{cc}\left(\mathrm{CHCl}_{3}-\mathrm{MeOH}\right.$, 22:1; Waters, Milford, MA, USA) to afford pure compounds 4 (4 mg) and 5 (3 mg). The $n-\mathrm{BuOH}$ soluble fraction $(10.4 \mathrm{~g})$ was subjected to a RP- $\mathrm{C}_{18}$ silica gel column chromatography with a gradient solvent system of $\mathrm{MeOH}-\mathrm{H}_{2} \mathrm{O}$ $(0: 1 \rightarrow 1: 1)$ as the eluent to give nine fractions (B1-B9). Fraction B8 $(80 \mathrm{mg})$ was subjected to a $\mathrm{RP}^{-\mathrm{C}_{18}}$ silica Lobar A-column with $50 \% \mathrm{MeOH}$ as the eluent to give two sub-fractions (B81-B82). Sub-fraction B81 (30 mg) was further

${ }^{1}$ Natural Products Laboratory, College of Pharmacy, Sungkyunkwan University, Suwon, Korea; ${ }^{2}$ Department of Food Science and Biotechnology, Sungkyunkawn University, Suwon, Korea and ${ }^{3}$ Bio-organic Science Division, Pharmacology Research Center, Korea Research Institute of Chemical Technology, Teajeon, Korea

Correspondence: Professor Dr KR Lee, Natural Products Laboratory, College of Pharmacy, Sungkyunkwan University, 300 Chonchon-dong, Jangan-ku, Suwon 440-746, Korea. E-mail: krlee@skku.ac.kr

Received 6 February 2009; revised 19 March 2009; accepted 24 March 2009; published online 17 April 2009 
purified by $\mathrm{RP}-\mathrm{C}_{18}$ preparative HPLC, as described above to give the pure compound 1 (7 mg).

\section{Physico-chemical properties}

Macrolepiotin (1). Yellowish gum, $\left.[\alpha]_{\mathrm{D}}^{25}:-6.5(c) 0.25, \mathrm{MeOH}\right)$, UV $\lambda_{\max }$ $(\mathrm{MeOH}) \mathrm{nm}(\log \epsilon) 231$ (3.66), 280 (5.51), IR (KBr) 3443, 2253, 1662, 1028, $824,761 \mathrm{~cm}^{-1}$. ${ }^{1} \mathrm{H}$ - and ${ }^{13} \mathrm{C}-\mathrm{NMR}$ spectral data are shown in Table 1. FAB-MS $\mathrm{m} / \mathrm{z} 580[\mathrm{M}+\mathrm{H}]^{+}$. HR-FAB-MS (positive-ion mode) $\mathrm{m} / \mathrm{z} 580.2665\left([\mathrm{M}+\mathrm{H}]^{+}\right.$, $\mathrm{C}_{31} \mathrm{H}_{38} \mathrm{~N}_{3} \mathrm{O}_{8}$, calcd. for 580.2659).

\section{Test for cytotoxicity in vitro}

A sulforhodamin B bioassay (SRB) was used to determine the cytotoxicity of each compound against four cultured human cancer cell lines. ${ }^{15}$ The assays were performed at the Korea Research Institute of Chemical Technology. The cell lines used were A549 (non-small-cell lung carcinoma), SK-OV-3 (ovary malignant ascites), SK-MEL-2 (skin melanoma) and HCT (colon adenocarcinoma). Doxorubicin was used as the positive control. The cytotoxicities of doxorubicin against A549, SK-OV-3, SK-MEL-2 and HCT cell lines were IC $_{50}$ $0.16,0.38,0.04$ and $0.82 \mu \mathrm{M}$, respectively.

Compound $\mathbf{1}$ was obtained as a yellowish gum, and was found to be positive for Dragendorff's reagent. Its molecular formula was determined to be $\mathrm{C}_{31} \mathrm{H}_{37} \mathrm{~N}_{3} \mathrm{O}_{8}$ from the $[\mathrm{M}+\mathrm{H}]^{+}$peak at $\mathrm{m} / \mathrm{z} 580.2665$ (calcd. for $\mathrm{C}_{31} \mathrm{H}_{38} \mathrm{~N}_{3} \mathrm{O}_{8} 580.2659$ ) in the positive-ion high-resolution (HR)-FAB-MS spectrum. The IR spectrum indicated that 1 possessed

Table $1{ }^{1} \mathrm{H}$ - and ${ }^{13} \mathrm{C}$-NMR data of 1

\begin{tabular}{|c|c|c|}
\hline Position & $\delta_{C}$ & $\delta_{H}$ \\
\hline 1 & & $10.93(1 \mathrm{H}, \mathrm{s})$ \\
\hline 2 & 128.6 & \\
\hline 3 & 107.5 & \\
\hline $3 a$ & 126.1 & \\
\hline 4 & 117.7 & $7.45(1 \mathrm{H}, \mathrm{d}, 7.5)$ \\
\hline 5 & 118.7 & $7.00(1 \mathrm{H}, \mathrm{t}, 7.5)$ \\
\hline 6 & 121.1 & $7.08(1 \mathrm{H}, \mathrm{t}, 7.5)$ \\
\hline 7 & 111.1 & $7.34(1 \mathrm{H}, \mathrm{d}, 7.5)$ \\
\hline $7 a$ & 136.2 & \\
\hline 8 & 22.8 & $2.93(1 \mathrm{H}, \mathrm{m}), 3.18(1 \mathrm{H}, \mathrm{m})$ \\
\hline 9 & 56.4 & $3.96(1 \mathrm{H}, \mathrm{m})$ \\
\hline 10 & 169.4 & \\
\hline 11 & 39.1 & $4.21(1 \mathrm{H}, \mathrm{q}, 7.5)$ \\
\hline 12 & 19.0 & $1.41(3 \mathrm{H}, \mathrm{d}, 7.5)$ \\
\hline 13 & 180.4 & \\
\hline \multicolumn{3}{|c|}{$1^{\prime}$} \\
\hline $2^{\prime}$ & 173.4 & \\
\hline $3^{\prime}$ & 29.2 & $2.35(1 \mathrm{H}, \mathrm{m}), 2.60(1 \mathrm{H}, \mathrm{m})$ \\
\hline $4^{\prime}$ & 23.5 & $2.02(1 \mathrm{H}, \mathrm{m}), 2.27(1 \mathrm{H}, \mathrm{m})$ \\
\hline $5^{\prime}$ & 91.4 & $5.33(1 \mathrm{H}, \mathrm{dd}, 5.5,1.0)$ \\
\hline $6^{\prime}$ & 129.3 & \\
\hline $7^{\prime}, 11^{\prime}$ & 124.9 & $7.24(2 \mathrm{H}, \mathrm{dd}, 8.0,2.0)$ \\
\hline $8^{\prime}, 10^{\prime}$ & 115.1 & $6.76(2 \mathrm{H}, \mathrm{dd}, 8.0,2.0)$ \\
\hline $9^{\prime}$ & 155.2 & \\
\hline $5^{\prime}$-OMe & 52.6 & $3.16(3 \mathrm{H}, \mathrm{s})$ \\
\hline $1^{\prime \prime}$ & 64.3 & $3.76(d d, 9.0,6.5)$ \\
\hline $2^{\prime \prime}$ & 37.2 & $2.05(1 \mathrm{H}, \mathrm{m})$ \\
\hline $3^{\prime \prime}$ & 28.5 & $1.42(1 \mathrm{H}, \mathrm{m}), 1.65(1 \mathrm{H}, \mathrm{m})$ \\
\hline $4^{\prime \prime}$ & 11.7 & $0.96(3 \mathrm{H}, \mathrm{t}, 7.5)$ \\
\hline $5^{\prime \prime}$ & 15.0 & $1.01(3 \mathrm{H}, \mathrm{d}, 7.0)$ \\
\hline $6^{\prime \prime}$ & 174.2 & \\
\hline
\end{tabular}

NMR data were obtained in $500 \mathrm{MHz}$ for ${ }^{1} \mathrm{H}$ and $125 \mathrm{MHz}$ for ${ }^{13} \mathrm{C}$ in DMSO, and values in parentheses are coupling constants in $\mathrm{Hz}$. hydroxyl $\left(3443 \mathrm{~cm}^{-1}\right)$ and carbonyl $\left(1662 \mathrm{~cm}^{-1}\right)$ groups. Its UV spectrum revealed absorptions at 231 and $280 \mathrm{~nm}$, suggesting chromophores of amide functional group and benzene rings in the molecule. The physico-chemical properties of 1 are summarized in the Materials and methods section. The ${ }^{1} \mathrm{H}$ - and ${ }^{13} \mathrm{C}-\mathrm{NMR}$ spectral data of 1 are shown in Table 1.

The ${ }^{1} \mathrm{H}-\mathrm{NMR}$ spectrum (Table 1 ) of $\mathbf{1}$ showed signals for the presence of three methyl groups at $\delta_{\mathrm{H}} 0.96\left(\mathrm{t}, \mathrm{H}-4^{\prime \prime}\right), 1.01\left(\mathrm{~d}, \mathrm{H}-5^{\prime \prime}\right)$ and 1.41 (d, H-12), four methylene groups at $\delta_{\mathrm{H}} 1.42,1.65\left(\mathrm{~m}, \mathrm{H}-3^{\prime \prime}\right), 2.02,2.27$ (m, H-4'), 2.35, 2.60 (m, H-3') and 2.93, $3.18(\mathrm{~m}, \mathrm{H}-8)$, five methine groups at $\delta_{\mathrm{H}} 2.05\left(\mathrm{~m}, \mathrm{H}-2^{\prime \prime}\right), 3.76\left(\mathrm{dd}, \mathrm{H}-1^{\prime \prime}\right), 3.96(\mathrm{~m}, \mathrm{H}-9), 4.21$ $(\mathrm{q}, \mathrm{H}-11)$ and $5.33\left(\mathrm{dd}, \mathrm{H}-5^{\prime}\right)$ and one methoxyl group at $\delta_{\mathrm{H}} 3.16$ (s, 5'-OMe). The 1,4-disubstituted aromatic protons were observed at $\delta_{\mathrm{H}} 6.76\left(\mathrm{dd}, \mathrm{H}-8^{\prime}, 10^{\prime}\right), 7.24\left(\mathrm{dd}, \mathrm{H}-7^{\prime}, 11^{\prime}\right)$ and four 1,2-disubstituted aromatic protons were shown at $\delta_{\mathrm{H}} 7.00(\mathrm{t}, \mathrm{H}-5), 7.08(\mathrm{t}, \mathrm{H}-6), 7.34$ $(\mathrm{d}, \mathrm{H}-7)$ and $7.45(\mathrm{~d}, \mathrm{H}-4)$. A signal of downfield resonance at $\delta_{\mathrm{H}} 10.93$ ( $\mathrm{s}, \mathrm{H}-1)$ with no heteronuclear multiple quantum coherence (HMQC) correlations with any carbon signal was assignable to the amide proton. An analysis of ${ }^{1} \mathrm{H}$ - and ${ }^{13} \mathrm{C}-\mathrm{NMR}$ spectra together with $\mathrm{HMQC}$ indicated that 31 carbon signals of 1 were composed of 4 carbonyl carbons, 14 olefinic carbons (including 12 aromatic carbons, 2 quaternary carbons), 5 methine carbons (including 1 oxygenated methine carbon), 4 methylene carbons, 3 methyl carbons and 1 methoxyl carbon. Analysis of ${ }^{1} \mathrm{H},{ }^{1} \mathrm{H}$-COSY data, HMQC and heteronuclear multiple bond correlation (HMBC) experiments established the presence of three partial structures, namely lepiotin $\mathrm{B}$ (partial unit A), isoleucine (partial unit B) and indole derivative (partial unit C) (Figure 1).

The presence of lepiotin B (partial unit $\mathbf{A}$ ) in $\mathbf{1}$ was apparent from the two sets of methine signals $\left(\delta_{\mathrm{H}} / \delta_{\mathrm{C}} ; 6.76 / 115.1,7.24 / 124.9\right)$ on a 1,4-disubstituted aromatic ring, a methine signal $\left(\delta_{\mathrm{H}} / \delta_{\mathrm{C}} ; 5.33 / 91.4\right)$ adjacent to two hetero atoms and from a methyl signal $\left(\delta_{\mathrm{H}} / \delta_{\mathrm{C}} ; 3.16 /\right.$ 52.6). The presence of a $\gamma$-lactam ring was confirmed from the HMBC correlations, in which correlations of $\mathrm{H}^{-} 5^{\prime}$ with $\mathrm{C}-2^{\prime}\left(\delta_{\mathrm{C}} 173.4\right), \mathrm{C}-3^{\prime}$ $\left(\delta_{\mathrm{C}} 29.2\right)$ and $\mathrm{C}-4^{\prime}\left(\delta_{\mathrm{C}} 23.5\right)$ were observed. This signal at $\mathrm{H}-5^{\prime}$ was further coupled with a methoxyl group $\left(\delta_{\mathrm{C}} 52.6\right)$, which implied that the position of the methoxyl group was at $\mathrm{C}-5^{\prime}$. Therefore, the partial unit $\mathbf{A}$ was assigned as lepiotin $\mathrm{B}$ by the above evidence. The lepiotin $\mathrm{B}$, having a $\gamma$-lactam and a phenol ring, was an unusual alkaloid, and the main constituent isolated from this mushroom. ${ }^{9}$

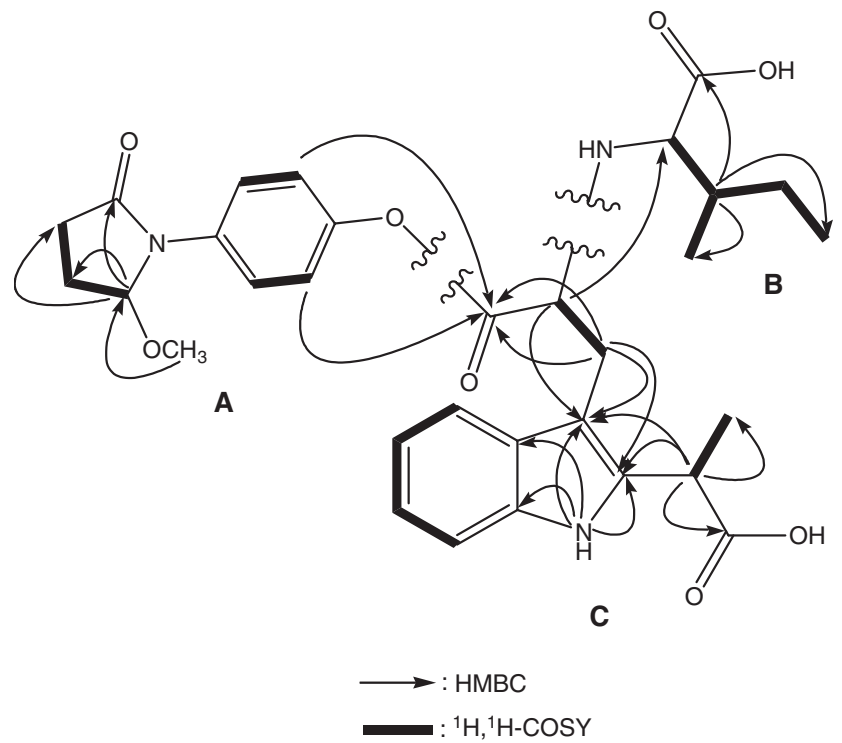

Figure 1 Key $\mathrm{HMBC},{ }^{1} \mathrm{H},{ }^{1} \mathrm{H}-\mathrm{COSY}$ correlations and partial units $(\mathbf{A}-\mathbf{C})$ of $\mathbf{1}$. 
<smiles>CCC(C)C(NC(Cc1c(C(C)C(=O)O)[nH]c2ccccc12)C(=O)Oc1ccc(N2C(=O)CCC2OC)cc1)C(=O)O</smiles><smiles>CC(C)[C@H](C)/C=C/[C@H](C)[C@H]1CCC2C3CC[C@H]4C[C@H](O)CC[C@]4(C)C3CC[C@]21C</smiles>

Figure 2 Structures of $\mathbf{1 - 5}$

Table 2 Cytotoxic activities of compounds (1-5) isolated from Macrolepiota neomastoidea

\begin{tabular}{lcccc}
\hline & \multicolumn{4}{c}{$C_{50}(\mu \mathrm{m})$} \\
\cline { 2 - 5 } Compound & $A 549$ & SK-OV-3 & SK-MEL-2 & HCT-15 \\
\hline $\mathbf{1}$ & $>30.0$ & $>30.0$ & $>30.0$ & $>30.0$ \\
$\mathbf{2}$ & 25.6 & 17.5 & 11.8 & 17.1 \\
$\mathbf{3}$ & 14.0 & 17.9 & 12.7 & 10.0 \\
$\mathbf{4}$ & $>30.0$ & $>30.0$ & $>30.0$ & 28.3 \\
$\mathbf{5}$ & $>30.0$ & 16.5 & $>30.0$ & $>30.0$ \\
Doxorubicin & 0.16 & 0.38 & 0.04 & 0.82 \\
\hline
\end{tabular}

$\mathrm{I}_{50}$ value of compounds against each cancer cell line, which was defined as the concentration $(\mu \mathrm{M})$ that caused $50 \%$ inhibition of cell growth in vitro.

A second partial unit $\mathbf{B}$ was assigned as isoleucine by the following NMR data. The ${ }^{1} \mathrm{H}-\mathrm{NMR}$ spectrum clearly indicated the appearance of two methyl groups at $\mathrm{C}-4^{\prime \prime}\left(\delta_{\mathrm{H}} 0.96\right)$ and $\mathrm{C}-5^{\prime \prime}\left(\delta_{\mathrm{H}} 1.01\right)$, a methylene group at $\mathrm{C}-3^{\prime \prime}\left(\delta_{\mathrm{H}} 1.42,1.65\right)$, as well as two methine groups at $\mathrm{C}-1^{\prime \prime}\left(\delta_{\mathrm{H}} 3.76\right)$ and $\mathrm{C}-2^{\prime \prime}\left(\delta_{\mathrm{H}} 2.05\right)$. The NMR resonances were similar to those of the isoleucine, ${ }^{16}$ which showed ${ }^{1} \mathrm{H},{ }^{1} \mathrm{H}$-COSY correlations between $\mathrm{H}-1^{\prime \prime} / \mathrm{H}-2^{\prime \prime}, \mathrm{H}-2^{\prime \prime} / \mathrm{H}-5^{\prime \prime}, \mathrm{H}-2^{\prime \prime} / \mathrm{H}-3^{\prime \prime}$ and $\mathrm{H}-3^{\prime \prime} / \mathrm{H}-$ $4^{\prime \prime}$. In addition, correlations were observed between $\mathrm{H}-2^{\prime \prime}\left(\delta_{\mathrm{H}} 2.05\right)$ and $\mathrm{C}-4^{\prime \prime}\left(\delta_{\mathrm{C}} 11.7\right), \mathrm{C}-5^{\prime \prime}\left(\delta_{\mathrm{C}} 15.0\right)$ and $\mathrm{C}-6^{\prime \prime}\left(\delta_{\mathrm{C}} 174.2\right)$ in the HMBC spectrum.

The remaining fragment consisting of $\mathrm{C}_{14} \mathrm{H}_{13} \mathrm{NO}_{3}$ was elucidated as an indole derivative (partial unit $\mathbf{C}$ ) by the interpretation of the ${ }^{1} \mathrm{H},{ }^{1} \mathrm{H}$-COSY, HMQC and HMBC data. The presence of the indole skeleton was apparent from 1,2-disubstituted aromatic ring signals $\left(\delta_{\mathrm{H}} ; 7.00(\mathrm{t}, \mathrm{H}-5), 7.08\right.$ (t, H-6), 7.34 (d, H-7), 7.45 (d, H-4), $\delta_{\mathrm{C}}$;

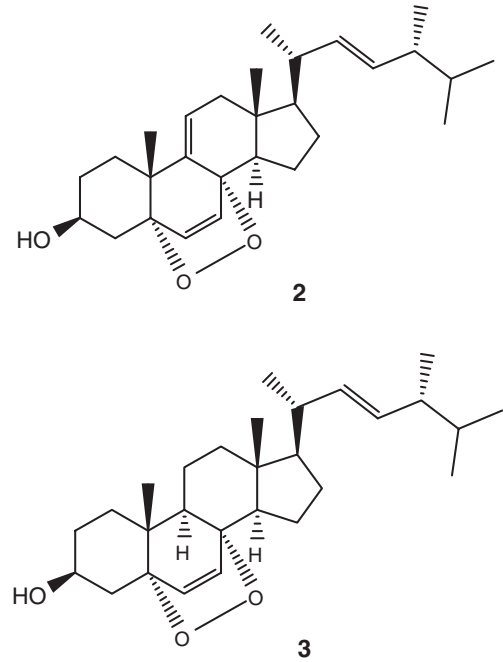

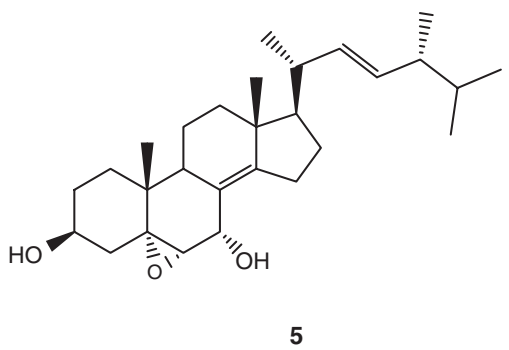

$111.1,117.7,118.7,121.1,126.1,136.2)$. The downfield signal (NH-1) of an amide proton showed HMBC correlation to four quaternary olefinic carbons (C-2, 3, 3a, 7a) (Figure 1). In addition, ${ }^{1} \mathrm{H},{ }^{1} \mathrm{H}$-COSY correlation between the methyl proton signal at $\delta_{\mathrm{H}} 1.41$ $(\mathrm{d}, \mathrm{H}-12)$ and the methine proton signal at $\delta_{\mathrm{H}} 4.21(\mathrm{q}, \mathrm{H}-11)$ and $\mathrm{HMBC}$ correlations between the methine proton signal at $\delta_{\mathrm{H}} 4.21(\mathrm{q}$, $\mathrm{H}-11)$ and $\mathrm{C}-2\left(\delta_{\mathrm{C}} 128.6\right), \mathrm{C}-3\left(\delta_{\mathrm{C}} 107.5\right), \mathrm{C}-12\left(\delta_{\mathrm{C}} 19.0\right)$ and $\mathrm{C}-13$ $\left(\delta_{\mathrm{C}} 180.4\right)$ were observed. This suggested that the propionic acid was located at C-2. HMBC correlations from methylene proton signals at $\delta_{\mathrm{H}} 2.93,3.18(\mathrm{~m}, \mathrm{H}-8)$ to $\mathrm{C}-2\left(\delta_{\mathrm{C}} 128.6\right), \mathrm{C}-3$ ( $\left.\delta_{\mathrm{C}} 107.5\right), \mathrm{C}-9$ $\left(\delta_{\mathrm{C}} 56.4\right)$ and $\mathrm{C}-10\left(\delta_{\mathrm{C}}\right.$ 169.4) suggested a connection between the indole skeleton and 2-amino propionic acid through carbon C-3. It was assumed that this indole derivative belonged to a small group of indolyl carboxylic acids, which were isolated from solvent extracts of indole-supplemented supernatants of Escherichia coli and Corynebacteria. ${ }^{17}$ It presented a similar structure to 2-(2-tryptophanyl) lactic acid, obtained from the condensation reaction between tryptophan and pyruvic acid. ${ }^{17}$

The three partial structures $\mathbf{A}, \mathbf{B}$ and $\mathbf{C}$ were built into a full structure from the HMBC correlations (Figure 1). The isoleucine function was attached at C- 9 of the indole derivative by the HMBC correlation between $\mathrm{H}-9\left(\delta_{\mathrm{H}} 3.96\right)$ and C-1" $\left(\delta_{\mathrm{C}} 64.3\right)$. Biogenetically, this resembled konbamidin, ${ }^{18}$ and may be derived from 1 mol each of isoleucine and a third partial unit, the indole derivative. The ${ }^{13} \mathrm{C}$-NMR chemical shift of C-10 at $\delta_{\mathrm{C}} 169.4$ indicated the presence of an ester bond. This connection was confirmed from the HMBC correlation between $\mathrm{H}-8^{\prime}, 10^{\prime}\left(\delta_{\mathrm{H}} 6.76\right)$ and $\mathrm{C}-10\left(\delta_{\mathrm{C}} 169.4\right)$. Using the above data, the structure of $\mathbf{1}$ was assembled as shown in Figure 2. The stereochemistry of $\mathbf{1}$ has not yet been determined and remains to be studied in detail. 
Cytotoxic activities of the isolated compounds (1-5) were evaluated against the A549, SK-OV-3, SK-MEL-2 and HCT15 human tumor cell lines in vitro using the SRB assay. Compounds 2 and $\mathbf{3}$ showed moderate cytotoxicity against A549, SK-OV-3, SK-MEL-2 and HCT15 cell lines as shown in Table 2. The mechanism of cytotoxic activity of the ergosterol peroxide was not well studied, but the cytotoxicity of the peroxide compounds (2 and 3) was probably ascribed to the presence of the peroxide functional group. ${ }^{19} \mathrm{Com}-$ pounds $\mathbf{4}$ and $\mathbf{5}$ showed moderate cytotoxicity against HCT15 and SKOV-3 cell lines, respectively.

\section{ACKNOWLEDGEMENTS}

The authors thank Drs EJ Bang, SG Kim, and JJ Seo at the Korea Basic Science Institute for the NMR and MS spectra measurements. This work was supported by the grant 'Classification of Poisonous Mushrooms and Study of Investigating Toxic Constituents, 2006’ from the Rural Development Administration in Korea.

1 Dulger, B., Hacioglu, N., Aydin, G. \& Uzun, Y. Antimicrobial activity of three Macrolepiota species from Turkey. Asian J. Chem. 20, 3945-3948 (2008).

2 Vetter, J. Trypsin inhibitor activity of basidiomycetous mushrooms. Eur. Food Res. Technol. 211, 346-348 (2000)

3 Barros, L., Baptista, P., Correia, D. M., Morais, J. S. \& Ferreira, I. C. F. R. Effects of conservation treatment and cooking on the chemical composition and antioxidant activity of Portuguese wild edible mushrooms. J. Agric. Food Chem. 55, 4781-4788 (2007).

4 Puttaraju, N. G., Venkateshaiah, S. U., Dharmesh, S. M., Urs, S. M. N. \& Somasundaram, R. Antioxidant activity of indigenous edible mushrooms. J. Agric. Food Chem. 54, 9764-9772 (2006).
5 Kolcuoglu, Y., Colak, A., Sesli, E., Yildirim, M. \& Saglam, N. Comparative charaterization of monophenolase and diphenolase activities from a wild edible mushroom (Macrolepiota mastoidea). Food Chem. 101, 778-785 (2006).

6 Senatore, F. Chemical constituents of some species of Agaricaceae. Biochem. Syst. Ecol. 16, 601-604 (1988).

7 Kim, K. H., Choi, S. U., Park, K. M., Seok, S. J. \& Lee, K. R. Cytotoxic constituents of Amanita subjunquillea. Arch. Pharm. Res. 31, 579-586 (2008).

8 Lehmann, P. F. \& Khazan, U. Mushroom poisoning by Chlorophyllum molybdites in the Midwest United States. Cases and a review of the syndrome. Mycopathologia 118, 3-13 (1992).

9 Tomihisa, O., Hiroyuki, I., Genjiro, K. \& Yoshiteru, O. Lepiotins A and B, new alkaloids from the mushrooms, Macrolepiota neomastoidea and Chlorophyllum molybdites. Heterocycles 47, 883-891 (1998).

10 Kim, K. H., Lee, I. K., Park, K. M., Kim, W. K. \& Lee, K. R. Isolation of $\gamma$-lactam alkaloids from the Macrolepiota neomastoidea. Bull. Korean Chem. Soc. 29, 1591-1593 (2008).

11 Kazuko, Y., Mizuho, I., Shigenobu, A., Eiko, M. \& Satoshi, K. Two new steroidal derivatives from the fruit body of Chlorophyllum molybdites. Chem. Pharm. Bull. 49, 1030-1032 (2001).

$12 \mathrm{Xu}, \mathrm{M}$. L. et al. Cytotoxic constituents isolated from the fruit bodies of Hypsizigus marmoreus. Arch. Pharm. Res. 30, 28-33 (2007).

13 Noboru, S. et al. Sterol analysis of DMI-resistant and sensitive strains of Venturia inaequalis. Phytochemistry 41, 1301-1308 (1996).

14 Yue, J. M., Chen, S. N., Lin, Z. W. \& Sun, H. D. Sterols from the fungus Lactarium volemus. Phytochemistry 56, 801-806 (2001).

15 Skehan, P. et al. New colorimetric cytotoxicity assay for anticancer-drug screening. J. Natl. Cancer Inst. 82, 1107-1112 (1990).

16 Krasnoff, S. B., Reategui, R. F., Wagenaar, M. M., Gloer, J. B. \& Gibson, D. M. Cicadapeptins I and II: new aib-containing peptides from the entomopathogenic fungus Cordyceps heteropoda. J. Nat. Prod. 68, 50-55 (2005).

17 Thomas, R. G. et al. Indolyl carboxylic acids by condensation of indoles with $\alpha$-keto acids. J. Nat. Prod. 63, 596-598 (2000).

18 Shinonaga, H., Shigemori, H. \& Kobayashi, J. Konbamidin, a new indole alkaloid from the okinawan marine sponge Ircinia sp. J. Nat. Prod. 57, 1603-1605 (1994).

19 Takei, T., Yoshida, M., Ohnishi-Kameyama, M. \& Kobori, M. Ergosterol peroxide, an apoptosis-inducing component isolated from Sarcodon aspratus (Berk.) S. Ito. Biosci. Biotechnol. Biochem. 69, 212-215 (2005). 